\title{
EFFECT OF DATES CONSUMPTION ON THE INCREASE OF HB LEVEL ON X GRADE FEMALE STUDENTS AT MA DARUL A'MAL METRO
}

\section{PENGARUH KONSUMSI BUAH KURMA TERHADAP PENINGKATAN KADAR HB PADA SISWI KELAS X MA DARUL A'MAL METRO}

\section{Fakhrunnisa Ahmad, Sri Lestariningsih, Gangsar Indah Lestari}

Program Studi Kebidanan Metro Politeknik Kesehatan Tanjungkarang

Article Info
Article history:
Received Des $3^{\text {rd }}, 2017$
Revised Jan $20^{\text {th }}, 2018$
Accepted Mar $3^{\text {rd }}, 2018$

\section{Keyword:}

\section{Dates}

$\mathrm{Hb}$

\section{Kata Kunci : \\ Buah Kurma \\ $\mathrm{Hb}$}

\begin{abstract}
ABSTRAK
Woman have anemia risk because of monthly period and iron lost about 1,4 $\mathrm{mg} /$ day. Anemia incidence on girls in Metro City was about $67 \%$. Presurvey result at Darul A'mal Senior High School showed from 11 students whose $\mathrm{Hb}$ level were checked, there were 8 students who had anemia $(72.7 \%)$. Anemia can be overcome by eating dates. This research aims to know the effect of eating dates to the increase of $\mathrm{Hb}$ level on tenth grade female students at Darul A'mal Senior High School Metro. The research used one group pretest posttest from pre-experiment research design. Sample was taken using quote sampling with total of 20 respondents. Data were collected using checklist and mechanical devices (digital $\mathrm{Hb}$ ). The data were analyzed by univariate analyst using median and bivariate $t$ test dependen on parametric (wiloxon test). The research result obtained median on $\mathrm{Hb}$ level measurement before was $11,2 \mathrm{gr} / \mathrm{dl}$ and $11,7 \mathrm{gr} / \mathrm{dl}$ after. The result of statistic test wilcoxon $p$ value was 0,031 . The conclusion of this research, there is an influence of eating dates to the increase of $\mathrm{Hb}$ level on tenth grade female students at Darul A'mal Metro Senior High School. It is expected that the students are given dates everyday after taking dawn prayers in congegration or breakfast to prevent and handle anemia at Darul A'mal Senior High School.
\end{abstract}

Wanita berisiko terkena anemia dikarenakan mengalami menstruasi setiap bulan dan akan kehilangan besi sekitar 1,4 mg per hari. Kejadian anemia pada remaja perempuan di Kota Metro sebesar 67\%. Hasil prasurvey di MA Darul A'mal dari 11 siswi yang dilakukan pemeriksaan kadar $\mathrm{Hb}$ terdapat 8 siswi yang mengalami anemia (72,7\%). Anemia dapat diatasi dengan mengonsumsi kurma. Penelitian ini bertujuan untuk mengetahui adakah pengaruh konsumsi buah kurma terhadap peningkatan kadar $\mathrm{Hb}$ pada siswi kelas X MA Darul A'mal Metro. Penelitian ini menggunakan rancangan one group pretest posttest dari desain penelitian praeksperimen. Pengambilan sampel menggunakan quota sampling dengan jumlah 25 responden. Pengumpulan data menggunakan check list dan alat mekanik ( $\mathrm{Hb}$ digital). Analisis univariat menggunakan median dan analisis bivariat menggunakan uji $t$ dependen non parametrik (uji wilcoxon). Hasil penelitian diperoleh median pada pengukuran kadar $\mathrm{Hb}$ sebelum adalah $11,2 \mathrm{gr} / \mathrm{dL}$ dan pada pengukuran kadar $\mathrm{Hb}$ sesudah adalah 11,7 gr/dL. Hasil uji statistik wilcoxon $p$ value $=0,031$. Simpulan penelitian adalah terdapat pengaruh konsumsi buah kurma terhadap peningkatan kadar $\mathrm{Hb}$ pada siswi kelas X MA Darul A'mal Metro. Diharapkan agar para siswi diberikan tujuh butir buah kurma setiap hari pada saat selesai shalat Subuh berjamaah atau sarapan untuk mencegah dan menangani anemia di MA Darul A'mal.

\section{Corresponding Author:}

Sri Lestariningsih

Program Studi Kebidanan Metro

Politeknik Kesehatan Tanjungkarang,

Email: lestariningsihs@yahoo.co.id 


\section{PENDAHULUAN}

Kejadian anemia merupakan masalah yang paling banyak ditemukan pada remaja putri. Akan tetapi remaja sering kurang mendapatkan perhatian dalam program pelayanan kesehatan ${ }^{1}$. Anemia defisiensi zat besi akan berdampak cepat merasa lelah, merasa lesu, atau tidak berkonsentrasi dengan baik ${ }^{2}$. Anemia menyebabkan jantung berdenyut kencang dan napas tersengal/pendek saat melakukan aktifitas ringan, pucat (kulit, bibir, gusi, mata, kulit kuku, dan telapak tangan), nyeri dada, pusing, dan mata berkunang-kunang, tangan dan kaki dingin atau mati rasa, serta kemampuan akademik menurun ${ }^{1}$.

Anemia disebabkan oleh defisiensi zat besi, asam folat, dan/atau vitamin $B_{12}$; semuanya berakar pada asupan yang tidak adekuat, dan kecacingan yang masih tinggi. ${ }^{3}$ Anemia disebabkan dari perdarahan berat maupun ringan (menstruasi), serta kekurangan zat besi, vitamin $B_{12}$, vitamin $B_{6}$, vitamin $C$, atau tembaga ${ }^{2}$. Penyebab anemia karena gizi yang paling umum disebabkan oleh kekurangan zat besi atau asam folik.

WHO (2004) memperkirakan prevalensi anemia di seluruh dunia sekitar dua milyar. Defisiensi zat besi merupakan penyebab utama anemia di dunia $(50-80 \%)$, sehingga prevalensi anemia sering digunakan untuk pendekatan anemia defisiensi zat besi ${ }^{1}$. Berdasarkan data Riskesdas 2013 menunjukkan secara nasional prevalensi anemia adalah $21,7 \%{ }^{4}$. Prevalensi anemia pada remaja (15-24 tahun) sebesar $18,4 \%^{4}$. Kejadian anemia pada perempuan dewasa di Lampung adalah $25,9 \%^{5}$. Di Kota Metro prevalensi anemia pada remaja perempuan usia $15-19$ sebesar $67 \%$.

Mengonsumsi kurma dapat membantu mengatasi anemia, karena di dalam kurma terkandung zat besi, yaitu $1,2 \mathrm{mg} / 100$ gram kurma. Dr. Naufal mengemukakan bahwa mengonsumsi 10 butir kurma setiap hari dapat memenuhi 10\% kebutuhan zat besi $(1 \mathrm{mg})$ mengemukakan mengonsumsi buah kurma 7 butir di waktu Dhuha dapat meningkatkan kadar $\mathrm{Hb}$ (mengatasi anemia), sesuai dengan yang diajarkan Nabi Muhammad SAW ${ }^{7,8}$. Siapa pun yang pagi-pagi makan tujuh buah kurma ajwah maka pada hari itu ia tidak mudah keracunan dan terserang penyakit seperti yang tercantum dalam hadits yang diriwayatkan oleh Bukhari dan Muslim ${ }^{9}$.

Berdasarkan penelitian para ilmuwan, buah kurma kaya dengan protein, serat gula, vitamin $\mathrm{A}$ dan $\mathrm{C}$, serta mineral seperti zat besi, kalsium, sodium, dan potasium. Kandungan protein di dalam kurma sebesar 1,8-2,0\%; serat sebanyak 2,0-4,0\%; dan glukosa sebesar 50 $70 \%$. Selain mengandung energi gula yang kaya, kurma juga mengandung garam alkalin yang mampu menambah keasaman darah yang berfungsi untuk mengimbangi pengaruh makanan karbohidrat berlebih ${ }^{10}$.

Berdasarkan hasil prasurvey di tiga MA di Kota Metro dilakukan pemeriksaan $\mathrm{Hb}$ menggunakan alat cek $\mathrm{Hb}$ digital ditemukan bahwa kejadian anemia remaja tertinggi adalah di MA Darul A'mal yaitu dari 11 siswi terdapat 8 siswi yang anemia $(72,7 \%)$, di MA Tuma'ninah Yasin dari 10 siswi terdapat 7 siswi yang anemia (70\%), dan di MA Al Muhsin dari 10 siswi terdapat 6 siswi yang anemia $60 \%$. Berdasarkan kejadian anemia siswi kelas X di MA Darul A'mal serta kandungan zat besi dan manfaat kurma untuk mengobati anemia, penulis berniat untuk melakukan penelitian mengenai "Pengaruh Konsumsi Buah Kurma terhadap Peningkatan Kadar Hb pada Siswi Kelas X MA Darul A'mal Metro".

\section{METODE PENELITIAN}

Penelitian ini menggunakan rancangan one group pretest posttest dari desain penelitian praeksperimen. Populasi penelitian adalah siswi MA Darul A'mal Metro bulan April 2017. Pengambilan sampel menggunakan quota sampling dengan jumlah 25 responden yang telah memenuhi kriteria inklusi dan eksklusi. Pengumpulan data anemia menggunakan alat mekanik ( $\mathrm{Hb}$ digital) sebelum dan sesudah mengonsumsi buah kurma. Pengumpulan data mengonsumsi buah kurma menggunakan check list. Analisis data univariat membuat tabel distribusi median/nilai tengah kadar $\mathrm{Hb}$ sebelum dan sesudah diberikan perlakuan berupa konsumsi buah kurma. Analisis data bivariat menggunakan uji t dependen non parametrik (uji wilcoxon) untuk membandingkan apakah terdapat pengaruh konsumsi buah kurma terhadap peningkatan kadar $\mathrm{Hb}$.

\section{HASIL DAN PEMBAHASAN}

Berdasarkan hasil uji kenormalan data menggunakan Shapiro-Wilk, diperoleh $\mathrm{p}$ value sebelum bernilai $0,04(p<0,05)$ dan hasil $p$ value sesudah bernilai $0,263(p>0,05)$. Maka data berdistribusi tidak normal, sehingga analisa bivariat dilakukan menggunakan uji $t$ 
dependen non parametrik (uji wilcoxon) untuk membandingkan kadar $\mathrm{Hb}$ sebelum dan sesudah responden mengonsumsi buah kurma.

\subsection{Distribusi Kadar Hb Sebelum dan Sesudah Mengonsumsi Buah Kurma}

Tabel 1. Distribusi Kadar Hb Sebelum dan Sesudah Mengonsumsi Buah Kurma

\begin{tabular}{ccccc}
\hline & Median & Minimum & Maksimum & SD \\
\hline Sebelum & 11,2 & 8,7 & 11,9 & 0,853 \\
\hline Sesudah & 11,7 & 8,6 & 13,5 & 1,357 \\
\hline
\end{tabular}

Diketahui nilai tengah/median pada pengukuran kadar $\mathrm{Hb}$ sebelum mengonsumsi kurma adalah $11,2 \mathrm{gr} / \mathrm{dL}$ dan nilai tengah/median pada pengukuran kadar $\mathrm{Hb}$ sesudah mengonsumsi kurma adalah $11,7 \mathrm{gr} / \mathrm{dL}$. Terlihat ada perbedaan nilai tengah pada kadar $\mathrm{Hb}$ antara sebelum dan sesudah mengonsumsi kurma sebesar $0,5 \mathrm{gr} / \mathrm{dL}$. Hasil pengukuran $\mathrm{Hb}$ sebelum mengonsumsi buah kurma kadar $\mathrm{Hb}$ terendah adalah $8,7 \mathrm{gr} / \mathrm{dL}$ dan kadar $\mathrm{Hb}$ tertinggi 11,9 $\mathrm{gr} / \mathrm{dL}$. Hasil pengukuran $\mathrm{Hb}$ sesudah mengonsumsi buah kurma kadar $\mathrm{Hb}$ terendah adalah $8,6 \mathrm{gr} / \mathrm{dL}$ dan kadar $\mathrm{Hb}$ tertinggi adalah 13,5 gr/dL. Terdapat $48 \%$ responden yang memiliki kadar $\mathrm{Hb}>12 \mathrm{gr} / \mathrm{dL}$ dan sebanyak $52 \%$ responden masih mengalami anemia. Rata-rata peningkatan kadar $\mathrm{Hb}$ setelah mengonsumsi buah kurma sebesar $0,59 \mathrm{gr} / \mathrm{dL}$.

Penelitian ini memiliki hasil lebih besar dibanding hasil penelitian terhadap remaja putri yang mengalami anemia, diberikan kurma sebagai upaya peningkatan kadar $\mathrm{Hb}$, didapatkan rata-rata peningkatan kadar $\mathrm{Hb}$ sebesar $0,46 \mathrm{gr} / \mathrm{dL}^{11}$.

Dewasa ini, kurma telah dijadikan bahan obat seperti sari kurma yang digunakan untuk obat demam berdarah, melancarkan susah buang air besar, mengobati anemia, kurang nafsu makan, insomnia, sakit tenggorokan, bahkan mencegah dan mengatasi stroke. Buah yang memiliki tekstur lembut ini menjadikan kurma sangat mudah untuk dicerna oleh lambung ${ }^{10}$. Kandungan gula dalam kurma tidak memerlukan pengolahan dalam tubuh, karena kandungan gula dalam kurma sudah berupa glukosa ${ }^{9}$.

\subsection{Pengaruh Konsumsi Buah Kurma terhadap Peningkatan Kadar Hb pada Siswi Kelas X MA Darul A'mal Metro}

Tabel 2. Pengaruh Konsumsi Buah Kurma terhadap Peningkatan Kadar Hb pada Siswi Kelas X MA Darul A'mal Metro

\begin{tabular}{ccccc}
\hline & Median & SD & Selisih & p value \\
\hline Sebelum & 11,20 & 0,853 & $-2,159$ & \multirow{2}{*}{0,031} \\
Sesudah & 11,70 & 1,357 & & \\
\hline
\end{tabular}

Temuan hasil pengukuran kadar $\mathrm{Hb}$ pada siswi kelas X MA Darul A'mal Metro pada responden sebanyak 25 siswi antara sebelum dan sesudah diberi perlakuan berupa mengonsumsi buah kurma terdapat perbedaan. Sebanyak $68 \%$ mengalami peningkatan kadar $\mathrm{Hb}, 28 \%$ mengalami penurunan kadar $\mathrm{Hb}$, dan $4 \%$ kadar $\mathrm{Hb}$ responden tetap. Perurunan kadar $\mathrm{Hb}$ tertinggi yaitu sebesar 2,1 gr/dL dan peningkatan tertinggi yaitu 2,2 $\mathrm{gr} / \mathrm{dL}$.

Diketahui hasil analisa bivariat uji wilcoxon $p=0,031(p<0,05)$. Standar deviasi pada kadar $\mathrm{Hb}$ sebelum mengonsumsi buah kurma adalah 0,853 dan standar deviasi pada kadar $\mathrm{Hb}$ sesudah mengonsumsi buah kurma adalah 1,357. Maka secara statistik terdapat pengaruh konsumsi buah kurma terhadap peningkatan kadar $\mathrm{Hb}$ pada siswi kelas X MA Darul A'mal.

Penelitian ini sejalan dengan penelitian Cholifah terhadap remaja putri yang mengalami anemia menyebutkan bahwa ada pengaruh kurma terhadap peningkatan kadar $\mathrm{Hb}$ pada remaja putri yang mengalami anemia kelas XI SMK Raden Umar Said Kudus ${ }^{11}$. Hasil penelitian didapatkan rata-rata peningkatan kadar $\mathrm{Hb}$ sebesar $0,46 \mathrm{gr} / \mathrm{dL}$, dan didapatkan $\mathrm{p}$ value $=0,008$. Rata-rata kenaikan kadar $\mathrm{Hb}$ pada penelitian yang dilakukan oleh peneliti lebih tinggi dibanding penelitian yang dilakukan Cholifah yaitu 0,59 gr/dL. Namun, hasil uji statistik pada penelitian yang dilakukan oleh peneliti lebih rendah dibanding penelitian yang dilakukan Cholifah yaitu $p$ value $=0,031$. Hal ini dapat dikarenakan pola makan sehari-hari, kurma yang dikonsumsi, dan lama mengonsumsi kurma berbeda. 
Penelitian ini sesuai dengan pendapat Rahayu bahwa buah kurma dapat mengatasi anemia. Rahayu mengemukakan mengonsumsi buah kurma 7 butir di waktu Dhuha dapat meningkatkan kadar $\mathrm{Hb}$ (mengatasi anemia), sesuai dengan yang diajarkan Nabi Muhammad $\mathrm{SAW}^{8}$. Kandungan Zat besi pada buah kurma lebih tinggi dibandingkan buah yang lain. Kandungan zat besi pada kurma sebesar $1,2 \mathrm{mg} / 100 \mathrm{gram}^{7}$, sedangkan kandungan zat besi dalam jeruk sebesar $0,4 \mathrm{mg}$ dan kandungan zat besi dalam pisang $0,5 \mathrm{mg}^{12}$.

\section{KESIMPULAN}

Nilai tengah/median pada pengukuran kadar $\mathrm{Hb}$ sebelum mengonsumsi kurma adalah $11,2 \mathrm{gr} / \mathrm{dL}$. Kadar $\mathrm{Hb}$ terendah adalah $8,7 \mathrm{gr} / \mathrm{dL}$ dan kadar $\mathrm{Hb}$ tertinggi $11,9 \mathrm{gr} / \mathrm{dL}$. Nilai tengah/median pada pengukuran kadar $\mathrm{Hb}$ sesudah mengonsumsi kurma adalah 11,7 gr/dL. Kadar $\mathrm{Hb}$ terendah adalah $8,60 \mathrm{gr} / \mathrm{dL}$ dan kadar $\mathrm{Hb}$ tertinggi adalah 13,5 gr/dL. Hasil uji wilcoxon $p=0,031(p<0,05)$. Maka secara statistik terdapat pengaruh pengaruh konsumsi buah kurma terhadap peningkatan kadar $\mathrm{Hb}$ pada siswi kelas X MA Darul A'mal.

\section{DAFTAR PUSTAKA}

[1] Briawan, Dodik, 2016, Anemia Masalah Gizi pada Remaja Wanita, EGC, Jakarta, 108 halaman.

[2] Health Media Nutrition Series, 1996, Wanita dan Nutrisi, Sinar Grafika Offset, Jakarta.

[3] Arisman, 2010, Gizi dalam Daur Kehidupan: Buku Ajar Ilmu Gizi Edisi 2, EGC, Jakarta, 275 halaman.

[4] Badan Litbang Kemenkes RI, 2013, Riset Kesehatan Dasar (Riskesdas) 2013.

[5] Badan Litbang Depkes RI, 2008, Riset Kesehatan Dasar (Riskesdas) 2007.

[6] Bidang Kesga dan Gizi Dinkes Kota Metro, 2016, Laporan Kegiatan Kesehatan Remaja Tingkat Kabupaten/Kota 2015.

[7] Hammad, Sa'id, 2014, Kedokteran Nabi, Aqwa Medika, Solo, 456 halaman.

[8] Rahayu, Mugi, 2015, Persalinan Maryam, PrayU, Yogyakarta.

[9] Rinanto, Joko, 2015, Keajaiban Resep Obat Nabi SAW, Qisthi Press, Jakarta, 352 halaman.

[10] Andriawan, Didik, 2015, Rahasia Hidup Sehat ala Nabi SAW, Al Fath Publishing, Solo, 176 halaman.

[11] Cholifah, Noor; Amalia, Elva, 2016, The 5th Urecol Proceeding, Aplikasi Pemberian Kurma Sebagai Upaya Peningkatan Kadar Hemoglobin pada Remaja Putri yang Mengalami Anemia, (online),

https://www.google.com/url?sa=t\&rct=i\&q=\&esrc=s\&source=web\&cd=1\&ved=0ahUKEwjsy 3 AncrUAhUFP48KHT-HAzcQFgglMAA\&url=http\%3A\%2F\%2Flpp.uad.ac.id\%2Fwpcontent\%2Fuploads\%2F2017\%2F05\%2F49.-noor-choliyah-381387.pdf\&usg=AFQjCNGJTF6A6DHfqSAefzIVEEmJKblas A\&cad=ria, Di akses pada 14 Juni 2017.

[12] Al-Fatah, Muhammad Hatta, 2011, Mukjizat Pengobatan Herbal dalam Al Quran, Mirqat. 